\title{
Role of gap junction channel in the development of beat-to-beat action potential repolarization variability and arrhythmias
}

János Magyar ${ }^{1,2}$, Tamás Bányász ${ }^{1}$, Norbert Szentandrássy ${ }^{1,3}$, Kornél Kistamás ${ }^{1}$, Péter P. Nánási ${ }^{1,3}$, Jonathan Satin ${ }^{4}$

${ }^{1}$ Department of Physiology, Faculty of Medicine, University of Debrecen, Hungary

${ }^{2}$ Division of Sport Physiology, Department of Physiology, Faculty of Medicine, University of

Debrecen, Hungary

${ }^{3}$ Department of Dental Physiology and Pharmacology, Faculty of Dentistry, University of

Debrecen, Hungary

${ }^{4}$ Department of Physiology, University of Kentucky, Lexington, KY USA

\section{Running title:}

Gap junctions and beat-to-beat variability of action potential repolarization

\section{Abstract}

The short-term beat-to-beat variability of cardiac action potential duration (SBVR) occurs as a random alteration of the ventricular repolarization duration. SBVR has been suggested to be more predictive of the development of lethal arrhythmias than the action potential prolongation or QT prolongation of ECG alone. The mechanism underlying SBVR is not completely understood but it is known that SBVR depends on stochastic ion channel gating, intracellular calcium handling and intercellular coupling.

Coupling of single cardiomyocytes significantly decreases the beat-to-beat changes in action potential duration (APD) due to the electrotonic current flow between neighboring cells. The magnitude of this electrotonic current depends on the intercellular gap junction resistance. Reduced gap junction resistance causes greater electrotonic current flow between cells, and reduces SBVR.

Myocardial ischaemia (MI) is known to affect gap junction channel protein expression and function. MI increases gap junction resistance that leads to slow conduction, APD and refractory period dispersion, and an increase in SBVR. Ultimately, development of reentry arrhythmias and fibrillation are associated post-MI. Antiarrhythmic drugs have proarrhythmic side effects requiring alternative approaches. A novel idea is to target gap junction channels. Specifically, the use of gap junction channel enhancers and inhibitors may help to reveal the precise role of gap junctions in the development of arrhythmias. Since cell-to-cell coupling is represented in SBVR, this parameter can be used to monitor the degree of coupling of myocardium.

Keywords: heart, gap junction, beat-to-beat variability, arrhythmia

\section{Introduction}

It has been estimated that about half of the patients suffering from heart failure die from an arrhythmia, accounting for $>500.000$ deaths per year worldwide. Research is focused biomarkers as predictors of arrhythmia development. The prolongation of QT interval is a risk factor and an important predictor for the development of arrhythmias, in particular Torsades de Pointes arrhythmia (TdP) [1]. Clinical observations, as well as canine and rabbit model experiments suggest that the short term beat-to-beat variability of cardiac action potential 
duration (SBVR) is a better predictor of drug-induced TdP arrhythmias than the measurement of repolarization prolongation alone [2-6]. It is likely that the development of SBVR is multifactorial and the electrotonic interactions among cardiac cells, namely the gap junction channels limit the temporal dispersion of repolarization. Changes in function, quantity, and location of gap junction channels alter cardiac impulse conduction, membrane refractoriness, leading to the development of arrhythmias [7, 8]. Therefore the alteration of gap junction channel function may represent a putative antiarrhythmic therapeutic target.

In this review we summarize the possible role of gap junction channels in the development of SBVR, arrhythmias, and important gap junction enhancer and inhibitor molecules.

\section{The short term beat-to-beat variability of cardiac action potential duration (SBVR)}

The SBVR or the beat-to-beat variability of the QT interval occurs as random variations of the ventricular repolarization duration or QT intervals in consecutive heart beats at stable rates [9-11]. The exact mechanism underlying SBVR is not completely understood. To the best of our knowledge the mechanism of SBVR is multifactorial including: stochastic ion-channel gating [12-14], pharmacological interventions influencing ion channels that operate during the action potential plateau and repolarization [2], periodic calcium release of sarcoplasmic reticulum [15], and electrotonic interactions among the cardiac cells can influence it $[10,12]$.

A number of different ion channels contribute to the action potential configuration. The membrane resistance varies during the different phases of the action potential [16]. Stochastic ion channel gating contributes to variable action potential morphologies on a beat by beat basis. Lemay et al. published that stochastic gating of certain ion channels (ion channels responsible for L-type calcium current, late sodium current, slow component of the delayed rectifier potassium current) contribute primarily to the action potential repolarization variability of single cardiac cells [13]. Our results underline the importance of stochastic channel gating in the development of SBVR, too. We have previously described that the size of early repolarization phase of canine ventricular action potential influences the gating of Ltype calcium channels [17], namely large early repolarization causes the reopening of calcium channels during the action potential plateau. That means that a small change in the transient outward potassium current $\left(\mathrm{I}_{\mathrm{to}}\right)$ modifies the process of early repolarization, the calcium current, and consequently the duration of action potential repolarization. 
The action potential duration (APD) and the SBVR is also modulated by intracellular calcium handling. Johnson et al. reported that in dog heart spontaneous calcium release leads to APD prolongation via increased $\mathrm{I}_{\mathrm{Ca}-\mathrm{L}}$, which in turn increased SBVR [15]. In agreement with these data buffering of intracellular calcium suppressed SBVR [2]. In a rabbit LQT2 model abnormal calcium handling preceded fluctuations in membrane potential [18].

It is well known among cardiac electrophysiologists that SBVR is smaller for multicellular heart preparations than for isolated cardiac cells [10], implicating the involvement of gap junction channel function to SBVR.

In canine and rabbit models inhibition of the rapid and slow components of the delayed rectifier potassium current $\left(\mathrm{I}_{\mathrm{Kr}}\right.$ and $\left.\mathrm{I}_{\mathrm{Ks}}\right)$, and augmentation of late $\mathrm{I}_{\mathrm{Na}}$ significantly increased SBVR and prolonged the duration of repolarization. In these experiments the increased SBVR better predicted the development of TdP arrhythmia than repolarization prolongation alone [3, 4, 19, 20]. Hinterseer et al. published similar findings in selected human patients [21] and it is also known that the successful antiarrhythmic treatment does not need to be accompanied by QT interval shortening [22, 23]. These results question the association between QT prolongation and the arrhythmia development. Thus, quantitative assessment of SBVR could be a reliable parameter to predict proarrhythmic conditions [3, 9, $11]$.

\section{The gap junction}

\subsection{The structure of gap junction}

Gap junction channels are involved in physiological and pathological processes such as embryonic development, cell differentiation, growth [24-26], pathogenesis of neuropathies [27], epilepsy [28], cardiovascular diseases [29], and arrhythmias [30, 31]. Numerous densely packed gap junction channels form clusters that directly connect the cytoplasmic compartment of cells [32]. The structure of these channels has been described by Unwin \& Zampighi in 1980 [33]. The gap junction channel is composed of two hemichannels (connexons), provided by each of two neighboring cells. The connexon consists of six connexin proteins. Each connexin has four transmembrane domains, two extracellular loops, one intracellular loop, and cytoplasmic-localized amino- and carboxy-termini $[34,35]$. The amino acid sequence of the transmembrane domains and extracellular loops are highly conserved among the different isoforms; however, the length of the connexin C-terminus is variable [36]. The C-terminus contains phosphorylation sites providing putative substrate sites to regulate the gap junction channel function [36]. 
Until now more than twenty different connexin encoding genes have been described in mouse and in human [37]. The variable C-termini length among isoforms contributes to differing molecular weight of connexins, thus giving rise to the classification of these proteins [38].

Gap junction channels are often composed of the same type of connexin, but it is also possible that the functional gap junction channel is composed of different connexin isoforms. For example, in atrium $\mathrm{Cx} 40$ and $\mathrm{Cx} 43$ isoforms are co-localized suggesting heterotypic connexons [39]. Although the structure of various connexin isoforms is very similar, the permeability, the $\mathrm{pH}$ sensitivity, and the voltage gating of the channels formed by different connexin isoforms may differ [34, 35, 40, 41].

\subsection{The distribution of gap junctions}

In the mammalian heart expresses Cx37, Cx40, Cx43, Cx45 and Cx50 isoforms. Cx37 is detected in the endocardial endothelium [42], while Cx50 was described in rat atrioventricular valves [43]. $\mathrm{Cx} 40, \mathrm{Cx} 43$ and $\mathrm{Cx} 45$ are the most abundant connexin isoforms of the working mammalian myocardial cells and the conduction system. Cx40 is mainly expressed in the atrium and in the conduction system [44-49], while Cx43 can be found both in atrial and ventricular cells but not in sinoatrial and atrioventricular nodes [46, 48-55]. Cx45 is preferentially expressed in sinoatrial and atrioventricular nodes, His-bundle and bundle branches [56-58]. More recently, Cx30.2 expression was described in mouse sinus node and in the conduction system, but the human ortholog Cx31.9 is not expressed in the human heart [59-61].

The biophysical properties of these gap junction channel isoforms are different (reviewed by Dhein [36]). The single channel conductance is about $200 \mathrm{pS}, 80 \mathrm{pS}$ and $20 \mathrm{pS}$, for $\mathrm{Cx} 40$, Cx43 and Cx45 channel, respectively [42, 62, 63]. The conductance values can be influenced by many factors such as intracellular calcium, magnesium, sodium ion concentration, $\mathrm{pH}$, hypoxia and the phosphorylation state of connexins $[34,36]$. If we take into account the different conductances of the gap junction channels and the non-uniform expression of the connexin isoforms, then gap junctions seem to form different functional compartments within the heart. This provides the basis of the impulse propagation from the sinoatrial node toward the working ventricular cells.

In addition to this functional compartmentalization, the gap junction channels are unevenly distributed in the cell membrane. The large portion of the densely packed gap junction channels are localized at the poles of cardiomyocytes [64], while the smaller portion 
can be found on the lateral side of these cells. These gap junctions conduct the electrical impulses both in longitudinal and transverse direction. The uneven distribution of gap junction channels around the cell causes an anisotropic conduction, namely the longitudinal conduction velocity is nearly twice as much as the transversal one. In rabbit ventricle cells these values were obtained to $56 \pm 10 \mathrm{~cm} / \mathrm{s}$ and $26 \pm 7 \mathrm{~cm} / \mathrm{s}$, respectively [65].

\subsection{Modulation of gap junction channel function}

Gap junction channel function can be regulated by the modification of connexin expression, rate of degradation, by phosphorylation, by localization, and by ionic and metabolic changes.

The transcription of $\mathrm{Cx} 43$ is controlled by homebox factors including Nxk2.5 and Irx3 $[66,67]$. Posttranslational modification regulates channel assembly, trafficking, gating, internalization, and protein degradation. Phosphorylation of different residues by protein kinase $\mathrm{C}(\mathrm{PKC})$ isoforms and the multiple phosphorylation of $\mathrm{Cx} 43$ may lead to either enhanced or reduced cell-to-cell communication [68-72]. Dephosphorylation of connexins by protein phosphatases seems also to regulate gap junction function [73, 74]. In ischaemia, dephosphorylation of $\operatorname{Ser}^{297}$ and $\operatorname{Ser}^{368}$ causes gap junction uncoupling which can be rescued by suppression of Cx43 dephosphorylation [75, 76]. Phosphorylation of $\operatorname{Ser}^{297}$ and $\operatorname{Ser}^{330}$ induces the internalization of gap junction [75], while dephosphorylation of $\operatorname{Ser}^{356}$ makes the gap junction less sensitive to acidosis and increased intracellular calcium concentration [77, 78]. These data suggest that $\mathrm{Cx} 43$ function cannot be simply evaluated by the altered balance between phosphorylation and dephosphorylation. A reduced rate of $\mathrm{Cx} 43$ expression, and/or increased rate of internalization, and protein degradation can contribute to reduced cell-to-cell coupling.

Most gap junction channels are located at the cell poles; however, in ischaemia a lateral redistribution occurs. $\mathrm{Cx} 43$ redistributes from the cell poles to the lateral side of the cardiomyocytes [79-81]. Reduced intracellular $\mathrm{pH}$ promotes unhooking of $\mathrm{Cx} 43$ from scaffolding proteins and movement of $\mathrm{Cx} 43$ from intercalated disk to lateral membrane. Therefore not only the total number of gap junction channel is important for the physiological impulse propagation but also the channel distribution within the cell membrane.

Increasing concentration of intracellular calcium ion, reduced $\mathrm{pH}$, and the loss of ATP is considered to be the main stimuli to cause acute reduction in gap junction conductance during ischaemia $[36,82]$. After the onset of ischaemia a progressive increase in intracellular calcium concentration and decrease in $\mathrm{pH}$ can be observed. Gap junction conductance 
decreases if the intracellular calcium concentration exceeds 320-560 nmol/l [83]. Poor coupling may lead to the development of unidirectional conduction block. Such a reduced gap junction conductance slows the impulse propagation and contributes to reentry arrhythmias.

\section{The effect of gap junction on short term beat-to-beat variability}

It is well known that the APD of single ventricular cells shows temporal variability. For example, guinea pig isolated ventricular cells with 20-40 ms APD changes were reported [10], while we observed 15-25 ms beat-to-beat APD changes on canine ventricular cells [unpublished data]. Action potentials recorded on multicellular ventricular preparations do not show this kind of beat-to-beat APD changes. Electrical coupling of isolated ventricular cells also reduces the alteration in the duration of consecutive action potentials [10, 13, 14].

Coupling cardiomyocytes with different intrinsic APD resulted in a common APD for both cells. When both coupled cells are excited, electrotonic current flows to delay the repolarization of the cell with short intrinsic APD, and simultaneously the loss of current accelerates the repolarization of the cell with intrinsically long APD [84]. The changes in APD are asymmetrical. Namely the cardiomyocyte with the relatively short action potential prolonged much less than the corresponding shortening in the long APD cardiomyocyte. This can be related to the changes in the membrane resistance during the action potential. The membrane resistance is larger in the course of plateau than during the action potential repolarization [10]. Therefore the same charge movement causes larger membrane potential change of plateau than along the process of repolarization due to Ohm's law. Coupling two cardiac cells with identical intrinsic action potential duration does not change APD but it reduces SBVR. The extent of SBVR reduction is larger in cases of asymmetrical cell pairs than that of symmetrical pairs [12].

In guinea pig single ventricular cells $\mathrm{I}_{\mathrm{Ks}}$ blockade causes action potential prolongation, increases SBVR, and induces early afterdepolarizations (EAD). Coupling of a cell with $\mathrm{I}_{\mathrm{Ks}}$ blockade to another cardiomyocyte with normal action potential repolarization eliminates the EAD readily and completely [10]. In these experiments SBVR reduced as well. This result suggests that as long as the gap junction resistance is low, a relatively high degree of junctional intercellular coupling can suppress the development and spreading of EAD [12].

The magnitude of electrotonic current flow between neighboring cells depends on the coupling resistance. Lesh et al. published that dispersion of action potential duration was reduced because low-resistance cellular coupling masked intercellular variability [84][10, 13]. Increases in coupling resistance or in gap junction channel resistance yields unmasking of 
differences in action potential duration $[12,84]$. In guinea pig ventricular cells the gap junction resistance has to be larger than $10 \mathrm{GOhm}$ to achieve a complete uncoupling and to restore the intrinsic APD of the cardiomyocytes [10]. Similar results were obtained by computer simulation models. Gap junction resistance over the range of successful impulse propagation influenced neither APD nor SBVR in a one-dimensional strand $[12,85]$.

Under pathological conditions such as ischaemia, increased coupling resistance leads to slowed conduction and reduced magnitude of electrotonic current flow between the cells. Consequentially, reduced APD masking resulted in dispersion of APD and refractory period, thus increasing SBVR $[12,86]$. Thus SBVR indicates the degree of myocardial coupling, as well [12]. APD dispersion is pronounced throughout the ischaemic area especially in the border zone $[87,88]$. The large APD variability and refractory period dispersion may result in a meandering activation pathway, conduction block, reentry arrhythmias [10, 84, 89], ventricular fibrillation, and sudden cardiac death [90-93].

\section{Gap junction enhancers and inhibitors}

A number of papers support the contention that reduced function of gap junction channels often associate with ischaemia and arrhythmias [75, 94-97]. Therefore the modification of gap junction channel function can be a target of arrhythmia treatment. The important known gap junction channel enhancer (Fig 1.) and inhibitor (Fig 2.) molecules are summarized next.

\subsection{Gap junction channel enhancers (Fig 1.)}

Antiarrhythmic peptides (AAP)

The common antiarrhythmic agents (Class I-IV) are targeted to transmembrane ion channels or cardiac receptors [98] but during arrhythmogenesis and action potential propagation, the conductance of gap junctions can be an important factor [99]. The first reported paper of these peptides was in 1980, when Aonuma et al. found a natural antiarrhythmic peptide (hexapeptide, H-Gly-Pro-Hyp-Gly-Ala-Gly) in bovine atrium, which improved the rhythmicity of cultured myocardial cell clusters [100].

\section{AAP10}

AAP10 (H-Gly-Ala-Gly-Hyp-Pro-Tyr-CONH 2$)$ was one of the first studied antiarrhythmic coupling peptides. AAP10 has a horseshoe-like spatial structure [101]. The electron density in 
the Tyr-benzene ring, the van der Waals bonds, and intramolecular H-bonds are important to achieve the biologically active conformation, as well as proline and hydroxyproline groups. AAP10 improved both electrical and metabolic coupling on transfected HeLa cells, rat and guinea pig cardiomyocytes $[98,102,103]$ in a concentration range of $50 \mathrm{nM}-1 \mu \mathrm{M}$. It was also shown that the incidence of sustained type Ib ventricular fibrillation was reduced by AAP10, with a reduction in dispersion [101]. AAP10-like rotigaptide, prevents Cx43 dephosphorylation [104] and the activity of this drug depends on activation of PKC $\alpha$. The specific PKC $\alpha$-inhibitor CGP54345 completely prevented its action [102]. In ischaemia the duration of the action potentials is shortened, dispersion (inhomogeneity) is increased, and homogeneity is decreased. Jozwiak and Dhein showed that ischaemia-related slowing of the activation wave propagation and increased repolarization inhomogeneities, were antagonized by AAP10 in the border zone [105].

\section{Rotigaptide (ZP123, GAP-486)}

The antiarrhythmic peptide rotigaptide (molecular formula $\mathrm{C}_{28} \mathrm{H}_{39} \mathrm{~N}_{7} \mathrm{O}_{9}, \mathrm{H}_{2} \mathrm{~N}$-Gly-D-Ala-GlyD-4Hyp-D-Pro-D-Tyr-Ac) or formerly ZP123 (developed by Zealand Pharmaceuticals, Glostrup, Denmark) can selectively increase gap junctional conductance without affecting other ion channels. The hexapeptide rotigaptide is constructed using a retro-all-D-amino acid design of AAP10 template. The L-amino acids substituted with D-isomers are expected to protect against enzymatic degradation. Rotigaptide plasma half-life was more than 10 days compared with less than 15 min for AAP10 [106]. The same research group described that rotigaptide and AAP10 have no effect on average APD, but rotigaptide prevented the increased APD dispersion caused by hypokalemic ischaemia. Rotigaptide prevents Cx43 dephosphorylation (of $\mathrm{Ser}^{297}$ and $\mathrm{Ser}^{368}$ ) in a model of global ischaemia [104]. This is important because in normal myocardium $\mathrm{Cx} 43$ is phosphorylated and becomes dephosphorylated during ischaemia [75]. The beat-to-beat variability of the epicardial activation pattern was stabilized by AAP10 and rotigaptide. Both peptides enhanced the homogeneity of sub-epicardial action potential duration by significantly reducing subepicardial dispersion [107]. The commonly used concentration of rotigaptide is $50-250 \mathrm{nM}$.

\section{Danegaptide (GAP134, ZP1609)}

Danegaptide (molecular formula $\quad \mathrm{C}_{14} \mathrm{H}_{17} \mathrm{~N}_{3} \mathrm{O}_{4}, \quad$ (2S,4R)-1-(2-aminoacetyl)-4benzamidopyrrolidine-2-carboxylic acid) is an orally administered modified dipeptide that 
mimicking the localization and the functional groups of AAP10 and rotigaptide at an average plasma concentration of $250 \mathrm{nM}$. Danegaptide reduces atrial fibrillation in a dog model and prevents conduction slowing in rat atrial strips [108]. Hennan et al. showed a robust cardioprotective effect that limited infarct size [109]. In contrast with AAP10, danegaptide decreased the dye uptake in C6 cells stably transfected with Cx43 [108]. Hence this compound may display favorable effects both at the level of gap junctions, as well as at the level of hemichannels [110].

\section{HP-5}

HP-5 (N-3-(4-hydroxyphenyl)propionyl, Pro-Hyp-Gly-Ala-Gly-OH) is a modified antiarrhythmic pentapeptide. HP-5 is a synthetic analogue that has been synthesized by altering the amino-acid sequence of AAP to produce a propionyl derivative [111]. In a rabbit ischaemia/reperfusion model the elevated dispersion of APD was reduced after HP-5 treatment and stayed unaltered during late ischaemia [112]. HP-5 reduced the dispersion of APD without altering APD and the shape of action potential, the effective refractory period, heart rate, and contractility.

\subsection{Gap junction channel inhibitors (Fig 2.)}

Glycyrrhetinic acid (GA)

Terpenes are a class of compounds composed of repeating 5-carbon units of hemiterpenes. Triterpenes are terpenes consisting of six isoprene units and have the molecular formula $\mathrm{C}_{30} \mathrm{H}_{48}$. The pentacyclic triterpenes are five-ring derivatives of dammarane having a chairchair-chair-boat configuration and can be classified into lupane, oleanane, ursane or glycyrrhizic acid groups, and are one group of promising secondary plant metabolites [113]. GA is an oleic acid from the Liquorice of the Glycyrrhiza glabra L. Glycyrrhiza contains a saponin glycoside called glycyrrhizin, which is the calcium and potassium salt of GA. While the GA is 50 times sweeter than sucrose, upon hydrolysis, the glycoside loses its sweet taste and is converted to the aglycone GA (molecular formula $\mathrm{C}_{30} \mathrm{H}_{46} \mathrm{O}_{4}$ ) plus two molecules of glucuronic acid. These agents inhibit intercellular transfer of metabolites, and this has been attributed to the inhibition of gap junctions [114]. GA has two isoforms, the 18- $\alpha-$ glycyrrhetinic acid (18- $\alpha$-GA) and its diastereomer, the 18- $\beta$-glycyrrhetinic acid (18- $\beta$-GA) and these block gap junctions in concentrations of about $50 \mu \mathrm{M}$ [115] and $5 \mu \mathrm{M}$ [116], respectively. Shi et al. demonstrated that $\beta_{2}$-AR-mediated signal transduction is enhanced after GA treatment by changing the location of Gas in lipid rafts [117]. Du et al. reported that 
$18-\beta-G A$ preferentially blocked the late sodium current without affecting HERG and Kv1.5 channels [118].

\section{Carbenoxolone (CBX)}

CBX (3ß-hydroxy-11-oxoolean-12-en-30-oic acid 3-hemisuccinate, molecular formula $\mathrm{C}_{34} \mathrm{H}_{50} \mathrm{O}_{7}$ ) is a synthetic, hemisuccinate derivative of $18-\beta$-GA with a steroid-like structure [119]. CBX is shown to reduce fat mass, plasma triglyceride and cholesterol levels in obese rodent models acting as a non-selective inhibitor of the 11- $\beta$-hydroxysteroid dehydrogenase 1 (11- $\beta$-HSD1) [120]. It also blocks L-type calcium channels [121], pannexin hemichannels [122], and gap junctions [123]. Thus CBX is not selective to gap junctions [124]. In some experiments CBX did not alter connexin 43 hemichannel $(\mathrm{Cx} 43 \mathrm{Hc})$ conductance [125]. In another study $\mathrm{CBX}$ has been proven to disrupt hemichannel packing and aggregation in vivo [126], and CBX acts indirectly by intercalating into the cell membrane, altering the local lipid environment to hinder plaque formation [127].

Tetradecanoylphorbol acetate (TPA)

Phorbol esters are natural products derived from Croton tiglium, the source of croton oil, and from other plants of the family Euphorbiaceae [128]. TPA (12-Tetradecanoylphorbol 13acetate, tumor-promoting phorbol ester, molecular formula: $\mathrm{C}_{36} \mathrm{H}_{56} \mathrm{O}_{8}$ ) is the biologically most active phorbol ester, the compound had extraordinarily high potency, being active at nanomolar concentrations $(10-300 \mathrm{nM})$. The myristate side chain makes the molecule highly lipophilic, and specific binding is therefore obscured by very high nonspecific uptake. Small structural changes in the molecule can markedly alter its activity. The elimination of the hydroxyl group at position 20 of phorbol led to complete loss of activity, and methylation of the hydroxyl group at position 4 led to a several hundred-fold loss in potency [129]. TPA is a specific regulator of PKC activity, therefore it could influence a wide variety of cellular processes related to gap junctions [130]. The connexin protein $\mathrm{Cx} 43$ is phosphorylated at $\mathrm{Ser}^{368}$ in response to TPA-stimulated PKC activation, which could be prevented by PKC inhibitors. TPA induced internalization and degradation of Cx43 in human lens epithelial cells [131] and completely inhibited the assembly of functional gap junctions [132].

\section{GAP26/GAP27}

Warner et al. developed motifs that included short sequence motifs, SRPTEK in extracellular loop 1 and SHVR in extracellular loop 2, as likely potent peptides for use in disrupting cell- 
cell communication. Mimetic peptides, called gap junction peptides (GAP26 and GAP27) contained amino acid sequence VCYDKSFPISHVR and SRPTEKTIFII, respectively [133, 134]. To test the efficacy of mimetic peptides, reporter dyes were designed, by which the uptake of the reporter dyes across $\mathrm{Cx} 43 \mathrm{Hc}$ became a reliable and routine method to demonstrate open or leaky Cx43 channels [135]. GAP26 and GAP27 (molecular formula: $\mathrm{C}_{70} \mathrm{H}_{107} \mathrm{~N}_{19} \mathrm{O}_{19} \mathrm{~S}$ and $\mathrm{C}_{60} \mathrm{H}_{101} \mathrm{~N}_{15} \mathrm{O}_{17}$, respectively) are powerful inhibitors of these hydrophilic transmembrane pathways with little or no immediate effects on gap junctions [136]. They attenuate ACh-induced arterial relaxation and reduce potassium-mediated smooth muscle repolarization in endothelium-intact vessels in vitro. Wright et al. described a beneficial effect of GAP27 on scratch wound closure rates that correlated with decreased gap junctional intercellular communication in cultured human keratinocytes and fibroblasts [137]. The same research group showed altered susceptibility of diabetic versus non-diabetic cells to GAP27 treatment. They found an up-regulation of Ser $^{368}$-phosphorylation by GAP27 in diabetic cells compared to non-diabetic cells [138]. Different studies used mainly protein concentrations of 100-250 $\mu \mathrm{M}$. Ko et al. demonstrated that the formation of functional gap junctions is temperature dependent, and that the truncated version of GAP27 (amino acid sequence SRPTEKTIF) that lacks the two required isoleucine residues could not inhibit dye transfer into the cell [139].

\section{The possible antiarrhythmic effects of gap junction modulators}

Antiarrhythmic drugs exert their effects on the ion channels responsible for cardiac action potential generation thus modifying the properties of membrane repolarization and impulse conduction. Besides their beneficial effects, antiarrhythmic drugs have proarrhythmic side effects as well. Certain diseases are known to affect gap junction channel protein expression and function causing arrhythmias [140-142]. Therefore, a novel idea is to target gap junction channels in arrhythmia treatment. This novel strategy can be straightforward only in those cases where the arrhythmia is based on reduced intercellular coupling.

The development of a gap-junction-targeted antiarrhythmic theory requires the better understanding of the contribution of these channels to the process of arrhythmogenesis. It is known that arrhythmia occurs in different phases of ischaemia [143, 144] and in these phases different processes may lead to reduced intercellular coupling. During the early phases of ischaemia closure of existing gap junction channels increase the gap junction resistance. Later the increased intercellular resistance is due to structural changes, the altered connexin/connexon synthesis/degradation and lateralization. Aside from these temporal 
changes of hypoxia, spatial changes have to be taken into account as well. Ischaemia divides the heart into non-ischemic and ischemic zones. These zones can be characterized by normal, reduced, or complete uncoupling. The spatial dispersion of repolarization with slow conduction increases the susceptibility to reentry arrhythmias.

The onset of ischaemia changes intracellular calcium concentration, causes acidification, loss of ATP, and altered phosphorylation of $\mathrm{Cx} 43$ increase gap junction resistance. These events are associated with slow conduction, APD and refractory period anisotropy, increased SBVR, reentry, and fibrillation. APD and refractory period dispersion are pronounced in the border zone of ischaemia [145]. In the border zone, the ischemic inexcitable cells and the viable cells are not completely uncoupled. Therefore the ischemic cells electronically depress the viable cells and may form an arrhythmogenic substrate [146, 147]. At this stage of ischaemia, administration of gap junction channel enhancers seems to be beneficial. The acidosis-induced increase in APD dispersion was prevented by ZP123 administration in Langendorff-pefused guinea pig hearts. ZP123 diminished conduction velocity slowing and heterogeneous repolarization [148]. AAP10 enhanced gap junction conduction in guinea pig cardiomyocytes [149]. In a canine long QT model AAP10 altered the phosphorylation state of $\mathrm{Cx} 43$. AAP10 prevented the increase of transmural dispersion of repolarization, and suppressed the development of TdP arrhythmias [150].

In certain cases enhanced coupling can be a disadvantage. Under physiological circumstances the region of excited cells supplies sufficient amount of electrical charge (source) for the cells of neighboring region to depolarize them (sink). In those cases when the source to sink ratio decreases, reduction in gap junction resistance may cause conduction delays and anterograde conduction block.[151].

In ischaemia the reduced intercellular coupling has advantages, as well. Ischaemia is associated with reduced sodium current $\left(\mathrm{I}_{\mathrm{Na}}\right)$ that may cause conduction block [148] whereas the structural inhomogeneity and the increased gap junction resistance restore conduction $[151,152]$. On the other hand reduced intercellular coupling can limit the spread of mediators of cell death and this way it may reduce the size of infarction [153]. Administration of gap junction channel inhibitors like carbenoxolone can partly close gap junctions, preventing these channels from further uncoupling during the prolonged ischaemia to provide antiarrhythmic protection similar to preconditioning [97]. Partial uncoupling of gap junctions prior to ischaemia by ischemic-preconditioning preserves the electrical coupling of cells during a subsequent ischemic insult, indicating that a partial closure of gap junctions may play a trigger role in the protection [94, 96, 154, 155]. GAP26 and GAP27 blocks calcium- 
triggered ATP release mediated by Cx43 hemichannels [156-159]. Hemichannels are not engaged to gap junctions, and they are open under several physiological and pathophysiological conditions [160]. In ischaemia uncontrolled ATP release through hemichannels may result in cellular ATP depletion. Administration of GAP26 before or after the ischaemia protected heart cells against hypoxia and reperfusion and decreased infarct size [161]. Increased hemichannel function could be a side effect of gap junction channel enhancer treatment, via greater loss of ATP [162]. GAP134 has beneficial effects. Namely GAP134 promotes intercellular coupling, enhances the conduction velocity, and simultaneously limits the cellular ATP release through hemichannels [110].

During the late phase of ischaemia structural changes can occur. Decreased quantity of $\mathrm{Cx} 43$, lateralization and fibrosis can be responsible for increased gap junction resistance and local slowing of conduction. The process of $\mathrm{Cx} 43$ synthesis, trafficking, and reduced degradation should be targeted to restore gap junction resistance. ZP123 had beneficial effects on acidosis-induced electrical uncoupling, and ZP123 increased Cx43 protein level in cultured neonatal rat ventricular myocytes after 24h [163]. This effect was due to the increased rate of Cx43 synthesis, decreased rate of degradation and phosphorylation [98, 164]. However, the computer model of Tveito et al. predicts that in case of a significant load of fibroblasts on the cardiomyocyte, the administration of gap junction channel enhancer ZP123 reduces conduction velocity, prone to reentrant arrhythmias and conduction block [165].

\section{Conclusion}

In this review we summarized the role of the gap junction channel in the development of SBVR and arrhythmias. We also reviewed the utility of gap junction enhancers and inhibitors.

Modulation of gap junction channels may be an interesting and novel strategy to treat certain types of arrhythmias such as ischaemia-induced arrhythmias. Many agents can affect gap junction resistance and various strategies should be useful to prevent arrhythmia development short and long term after the onset of ischaemia. Using known and new gap junction channel enhancers and inhibitors may also improve our understanding of the fundamental basis underpinning the pathophysiology of arrhythmogenesis.

\footnotetext{
Abbreviations

AAP, Antiarrhythmic peptides
} 
APD, action potential duration;

CBX, Carbenoxolone

EAD, early afterdepolarization

GA, Glycyrrhetinic acid (GA)

$\mathrm{I}_{\text {Ca-L, L-type inward calcium current; }}$

$\mathrm{I}_{\mathrm{Kr}}$, rapid delayed rectifier potassium current;

$\mathrm{I}_{\mathrm{Ks}}$, slow delayed rectifier potassium current;

$\mathrm{I}_{\mathrm{Na}}$, inward sodium current;

$\mathrm{I}_{\mathrm{to}}$, transient outward potassium current;

MI, Myocardial ischaemia

PKC protein kinase $\mathrm{C}$

SBVR short term beat-to-beat variability of cardiac action potential duration

TdP, Torsades de Pointes

TPA, Tetradecanoylphorbol acetate

\section{Conflict of interest}

The authors state no conflict of interest.

\section{Acknowledgement}

This work was supported by the Hungarian Scientific Research Foundation (OTKA-K109736, OTKA-K100151, OTKA-PD101171, OTKA-K101196, OTKA-NK104331). Further support was obtained from European Union and the State of Hungary, co-financed by the European Social Fund in the framework of TÁMOP-4.2.4.A/2-11/1-2012-0001 'National Excellence Program'.

Reference

[1] Thomsen MB, Volders PG, Beekman JD, Matz J, Vos MA. Beat-to-Beat variability of repolarization determines proarrhythmic outcome in dogs susceptible to drug-induced torsades de pointes. J Am Coll Cardiol, 2006; 48: 1268-76.

[2] Johnson DM, Heijman J, Pollard CE, Valentin JP, Crijns HJ, Abi-Gerges N, Volders PG. I(Ks) restricts excessive beat-to-beat variability of repolarization during betaadrenergic receptor stimulation. J Mol Cell Cardiol, 2010; 48: 122-30.

[3] Thomsen MB, Verduyn SC, Stengl M, Beekman JD, de Pater G, van Opstal J, Volders PG, Vos MA. Increased short-term variability of repolarization predicts d-sotalolinduced torsades de pointes in dogs. Circulation, 2004; 110: 2453-9.

[4] Lengyel C, Varro A, Tabori K, Papp JG, Baczko I. Combined pharmacological block of $\mathrm{I}(\mathrm{Kr})$ and $\mathrm{I}(\mathrm{Ks})$ increases short-term QT interval variability and provokes torsades de pointes. Br J Pharmacol, 2007; 151: 941-51. 
[5] van Opstal JM, Schoenmakers M, Verduyn SC, de Groot SH, Leunissen JD, van Der Hulst FF, Molenschot MM, Wellens HJ, Vos MA. Chronic amiodarone evokes no torsade de pointes arrhythmias despite QT lengthening in an animal model of acquired long-QT syndrome. Circulation, 2001; 104: 2722-7.

[6] Milberg P, Eckardt L, Bruns HJ, Biertz J, Ramtin S, Reinsch N, Fleischer D, Kirchhof P, Fabritz L, Breithardt G, Haverkamp W. Divergent proarrhythmic potential of macrolide antibiotics despite similar QT prolongation: fast phase 3 repolarization prevents early afterdepolarizations and torsade de pointes. J Pharmacol Exp Ther, 2002; 303: 218-25.

[7] Peters NS, Wit AL. Myocardial architecture and ventricular arrhythmogenesis. Circulation, 1998; 97: 1746-54.

[8] Janse MJ, Wit AL. Electrophysiological mechanisms of ventricular arrhythmias resulting from myocardial ischemia and infarction. Physiol Rev, 1989; 69: 1049-169.

[9] Hinterseer M, Beckmann BM, Thomsen MB, Pfeufer A, Ulbrich M, Sinner MF, Perz S, Wichmann HE, Lengyel C, Schimpf R, Maier SK, Varro A, Vos MA, Steinbeck G, Kaab S. Usefulness of short-term variability of QT intervals as a predictor for electrical remodeling and proarrhythmia in patients with nonischemic heart failure. Am J Cardiol, 2010; 106: 216-20.

[10] Zaniboni M, Pollard AE, Yang L, Spitzer KW. Beat-to-beat repolarization variability in ventricular myocytes and its suppression by electrical coupling. Am J Physiol Heart Circ Physiol, 2000; 278: H677-87.

[11] Tereshchenko LG, Han L, Cheng A, Marine JE, Spragg DD, Sinha S, Dalal D, Calkins $\mathrm{H}$, Tomaselli GF, Berger RD. Beat-to-beat three-dimensional ECG variability predicts ventricular arrhythmia in ICD recipients. Heart Rhythm, 2010; 7: 1606-13.

[12] Heijman J, Zaza A, Johnson DM, Rudy Y, Peeters RL, Volders PG, Westra RL. Determinants of beat-to-beat variability of repolarization duration in the canine ventricular myocyte: a computational analysis. PLoS Comput Biol, 2013; 9: e1003202.

[13] Lemay M, de Lange E, Kucera JP. Effects of stochastic channel gating and distribution on the cardiac action potential. J Theor Biol, 2011; 281: 84-96.

[14] Pueyo E, Corrias A, Virag L, Jost N, Szel T, Varro A, Szentandrassy N, Nanasi PP, Burrage K, Rodriguez B. A multiscale investigation of repolarization variability and its role in cardiac arrhythmogenesis. Biophys J, 2011; 101: 2892-902.

[15] Johnson DM, Heijman J, Bode EF, Greensmith DJ, van der Linde H, Abi-Gerges N, Eisner DA, Trafford AW, Volders PG. Diastolic spontaneous calcium release from the sarcoplasmic reticulum increases beat-to-beat variability of repolarization in canine ventricular myocytes after beta-adrenergic stimulation. Circ Res, 2013; 112: 246-56.

[16] Liu YM, DeFelice LJ, Mazzanti M. Na channels that remain open throughout the cardiac action potential plateau. Biophys J, 1992; 63: 654-62.

[17] Fulop L, Banyasz T, Magyar J, Szentandrassy N, Varro A, Nanasi PP. Reopening of L-type calcium channels in human ventricular myocytes during applied epicardial action potentials. Acta Physiol Scand, 2004; 180: 39-47.

[18] Nemec J, Kim JJ, Gabris B, Salama G. Calcium oscillations and T-wave lability precede ventricular arrhythmias in acquired long QT type 2. Heart Rhythm, 2010; 7: 1686-94.

[19] Schneider J, Hauser R, Andreas JO, Linz K, Jahnel U. Differential effects of human ether-a-go-go-related gene (HERG) blocking agents on QT duration variability in conscious dogs. Eur J Pharmacol, 2005; 512: 53-60. 
[20] Wu L, Shryock JC, Song Y, Belardinelli L. An increase in late sodium current potentiates the proarrhythmic activities of low-risk QT-prolonging drugs in female rabbit hearts. J Pharmacol Exp Ther, 2006; 316: 718-26.

[21] Hinterseer M, Thomsen MB, Beckmann BM, Pfeufer A, Schimpf R, Wichmann HE, Steinbeck G, Vos MA, Kaab S. Beat-to-beat variability of QT intervals is increased in patients with drug-induced long-QT syndrome: a case control pilot study. Eur Heart J, 2008; 29: 185-90.

[22] Mazur A, Roden DM, Anderson ME. Systemic administration of calmodulin antagonist $\mathrm{W}-7$ or protein kinase A inhibitor $\mathrm{H}-8$ prevents torsade de pointes in rabbits. Circulation, 1999; 100: 2437-42.

[23] Gbadebo TD, Trimble RW, Khoo MS, Temple J, Roden DM, Anderson ME. Calmodulin inhibitor W-7 unmasks a novel electrocardiographic parameter that predicts initiation of torsade de pointes. Circulation, 2002; 105: 770-4.

[24] Coutinho P, Qiu C, Frank S, Tamber K, Becker D. Dynamic changes in connexin expression correlate with key events in the wound healing process. Cell Biol Int, 2003; 27: 525-41.

[25] Noble BS, Reeve J. Osteocyte function, osteocyte death and bone fracture resistance. Mol Cell Endocrinol, 2000; 159: 7-13.

[26] Davies TC, Barr KJ, Jones DH, Zhu D, Kidder GM. Multiple members of the connexin gene family participate in preimplantation development of the mouse. Dev Genet, 1996; 18: 234-43.

[27] Bergoffen J, Scherer SS, Wang S, Scott MO, Bone LJ, Paul DL, Chen K, Lensch MW, Chance PF, Fischbeck KH. Connexin mutations in X-linked Charcot-Marie-Tooth disease. Science, 1993; 262: 2039-42.

[28] Samoilova M, Li J, Pelletier MR, Wentlandt K, Adamchik Y, Naus CC, Carlen PL. Epileptiform activity in hippocampal slice cultures exposed chronically to bicuculline: increased gap junctional function and expression. J Neurochem, 2003; 86: 687-99.

[29] Kwak BR, Mulhaupt F, Veillard N, Gros DB, Mach F. Altered pattern of vascular connexin expression in atherosclerotic plaques. Arterioscler Thromb Vasc Biol, 2002; 22: 225-30.

[30] de Groot JR, Wilms-Schopman FJ, Opthof T, Remme CA, Coronel R. Late ventricular arrhythmias during acute regional ischemia in the isolated blood perfused pig heart. Role of electrical cellular coupling. Cardiovasc Res, 2001; 50: 362-72.

[31] Dekker LR, Fiolet JW, VanBavel E, Coronel R, Opthof T, Spaan JA, Janse MJ. Intracellular $\mathrm{Ca} 2+$, intercellular electrical coupling, and mechanical activity in ischemic rabbit papillary muscle. Effects of preconditioning and metabolic blockade. Circ Res, 1996; 79: 237-46.

[32] Saffitz JE, Schuessler RB, Yamada KA. Mechanisms of remodeling of gap junction distributions and the development of anatomic substrates of arrhythmias. Cardiovasc Res, 1999; 42: 309-17.

[33] Unwin PN, Zampighi G. Structure of the junction between communicating cells. Nature, 1980; 283: 545-9.

[34] van Veen AA, van Rijen HV, Opthof T. Cardiac gap junction channels: modulation of expression and channel properties. Cardiovasc Res, 2001; 51: 217-29.

[35] Saez JC, Berthoud VM, Branes MC, Martinez AD, Beyer EC. Plasma membrane channels formed by connexins: their regulation and functions. Physiol Rev, 2003; 83: 1359-400.

[36] Dhein S. Gap junction channels in the cardiovascular system: pharmacological and physiological modulation. Trends Pharmacol Sci., 1998; 19: 229-241. 
[37] Willecke K, Jungbluth S, Dahl E, Hennemann H, Heynkes R, Grzeschik KH. Six genes of the human connexin gene family coding for gap junctional proteins are assigned to four different human chromosomes. Eur J Cell Biol, 1990; 53: 275-80.

[38] Sohl G, Willecke K. An update on connexin genes and their nomenclature in mouse and man. Cell Commun Adhes, 2003; 10: 173-80.

[39] van der Velden HM, Jongsma HJ. Cardiac gap junctions and connexins: their role in atrial fibrillation and potential as therapeutic targets. Cardiovasc Res, 2002; 54: 270-9.

[40] Burt JM, Spray DC. Inotropic agents modulate gap junctional conductance between cardiac myocytes. Am J Physiol, 1988; 254: H1206-10.

[41] Valiunas V, Gemel J, Brink PR, Beyer EC. Gap junction channels formed by coexpressed connexin40 and connexin43. Am J Physiol Heart Circ Physiol, 2001; 281: H1675-89.

[42] Reed KE, Westphale EM, Larson DM, Wang HZ, Veenstra RD, Beyer EC. Molecular cloning and functional expression of human connexin37, an endothelial cell gap junction protein. J Clin Invest, 1993; 91: 997-1004.

[43] Gourdie RG, Green CR, Severs NJ, Thompson RP. Immunolabelling patterns of gap junction connexins in the developing and mature rat heart. Anat Embryol (Berl), 1992; 185: 363-78.

[44] Davis LM, Rodefeld ME, Green K, Beyer EC, Saffitz JE. Gap junction protein phenotypes of the human heart and conduction system. J Cardiovasc Electrophysiol, 1995; 6: 813-22.

[45] Gros D, Jarry-Guichard T, Ten Velde I, de Maziere A, van Kempen MJ, Davoust J, Briand JP, Moorman AF, Jongsma HJ. Restricted distribution of connexin40, a gap junctional protein, in mammalian heart. Circ Res, 1994; 74: 839-51.

[46] Delorme B, Dahl E, Jarry-Guichard T, Briand JP, Willecke K, Gros D, TheveniauRuissy M. Expression pattern of connexin gene products at the early developmental stages of the mouse cardiovascular system. Circ Res, 1997; 81: 423-37.

[47] Miquerol L, Meysen S, Mangoni M, Bois P, van Rijen HV, Abran P, Jongsma H, Nargeot J, Gros D. Architectural and functional asymmetry of the His-Purkinje system of the murine heart. Cardiovasc Res, 2004; 63: 77-86.

[48] van Veen TA, van Rijen HV, van Kempen MJ, Miquerol L, Opthof T, Gros D, Vos MA, Jongsma HJ, de Bakker JM. Discontinuous conduction in mouse bundle branches is caused by bundle-branch architecture. Circulation, 2005; 112: 2235-44.

[49] Gourdie RG, Severs NJ, Green CR, Rothery S, Germroth P, Thompson RP. The spatial distribution and relative abundance of gap-junctional connexin40 and connexin43 correlate to functional properties of components of the cardiac atrioventricular conduction system. J Cell Sci, 1993; 105 ( Pt 4): 985-91.

[50] Manjunath CK, Page E. Cell biology and protein composition of cardiac gap junctions. Am J Physiol, 1985; 248: H783-91.

[51] Beyer EC, Paul DL, Goodenough DA. Connexin43: a protein from rat heart homologous to a gap junction protein from liver. J Cell Biol, 1987; 105: 2621-9.

[52] Yancey SB, John SA, Lal R, Austin BJ, Revel JP. The 43-kD polypeptide of heart gap junctions: immunolocalization, topology, and functional domains. J Cell Biol, 1989; 108: 2241-54.

[53] Kanter HL, Saffitz JE, Beyer EC. Cardiac myocytes express multiple gap junction proteins. Circ Res, 1992; 70: 438-44.

[54] Kirchhoff S, Kim JS, Hagendorff A, Thonnissen E, Kruger O, Lamers WH, Willecke $\mathrm{K}$. Abnormal cardiac conduction and morphogenesis in connexin 40 and connexin43 double-deficient mice. Circ Res, 2000; 87: 399-405. 
[55] van Rijen HV, van Veen TA, van Kempen MJ, Wilms-Schopman FJ, Potse M, Krueger O, Willecke K, Opthof T, Jongsma HJ, de Bakker JM. Impaired conduction in the bundle branches of mouse hearts lacking the gap junction protein connexin 40 . Circulation, 2001; 103: 1591-8.

[56] Coppen SR, Dupont E, Rothery S, Severs NJ. Connexin45 expression is preferentially associated with the ventricular conduction system in mouse and rat heart. Circ Res, 1998; 82: 232-43.

[57] Verheijck EE, van Kempen MJ, Veereschild M, Lurvink J, Jongsma HJ, Bouman LN. Electrophysiological features of the mouse sinoatrial node in relation to connexin distribution. Cardiovasc Res, 2001; 52: 40-50.

[58] Honjo H, Boyett MR, Coppen SR, Takagishi Y, Opthof T, Severs NJ, Kodama I. Heterogeneous expression of connexins in rabbit sinoatrial node cells: correlation between connexin isotype and cell size. Cardiovasc Res, 2002; 53: 89-96.

[59] Kreuzberg MM, Sohl G, Kim JS, Verselis VK, Willecke K, Bukauskas FF. Functional properties of mouse connexin30.2 expressed in the conduction system of the heart. Circ Res, 2005; 96: 1169-77.

[60] Gros D, Theveniau-Ruissy M, Bernard M, Calmels T, Kober F, Sohl G, Willecke K, Nargeot J, Jongsma HJ, Mangoni ME. Connexin 30 is expressed in the mouse sinoatrial node and modulates heart rate. Cardiovasc Res; 85: 45-55.

[61] Kreuzberg MM, Liebermann M, Segschneider S, Dobrowolski R, Dobrzynski H, Kaba R, Rowlinson G, Dupont E, Severs NJ, Willecke K. Human connexin31.9, unlike its orthologous protein connexin30.2 in the mouse, is not detectable in the human cardiac conduction system. J Mol Cell Cardiol, 2009; 46: 553-9.

[62] Bukauskas FF, Elfgang C, Willecke K, Weingart R. Biophysical properties of gap junction channels formed by mouse connexin 40 in induced pairs of transfected human HeLa cells. Biophys J, 1995; 68: 2289-98.

[63] Kwak BR, Hermans MM, De Jonge HR, Lohmann SM, Jongsma HJ, Chanson M. Differential regulation of distinct types of gap junction channels by similar phosphorylating conditions. Mol Biol Cell, 1995; 6: 1707-19.

[64] De Maziere AM, Scheuermann DW. Structural changes in cardiac gap junctions after hypoxia and reoxygenation: a quantitative freeze-fracture analysis. Cell Tissue Res, 1990; 261: 183-94.

[65] Dhein S, Krusemann K, Schaefer T. Effects of the gap junction uncoupler palmitoleic acid on the activation and repolarization wavefronts in isolated rabbit hearts. $\mathrm{Br} \mathrm{J}$ Pharmacol, 1999; 128: 1375-84.

[66] Oyamada M, Takebe K, Oyamada Y. Regulation of connexin expression by transcription factors and epigenetic mechanisms. Biochim Biophys Acta, 2013; 1828: 118-33.

[67] Scott MP, Tamkun JW, Hartzell GW, 3rd. The structure and function of the homeodomain. Biochim Biophys Acta, 1989; 989: 25-48.

[68] Lampe PD, Lau AF. Regulation of gap junctions by phosphorylation of connexins. Arch Biochem Biophys, 2000; 384: 205-15.

[69] Crow DS, Beyer EC, Paul DL, Kobe SS, Lau AF. Phosphorylation of connexin43 gap junction protein in uninfected and Rous sarcoma virus-transformed mammalian fibroblasts. Mol Cell Biol, 1990; 10: 1754-63.

[70] Swenson KI, Piwnica-Worms H, McNamee H, Paul DL. Tyrosine phosphorylation of the gap junction protein connexin43 is required for the pp60v-src-induced inhibition of communication. Cell Regul, 1990; 1: 989-1002.

[71] Salameh A, Dhein S. Adrenergic control of cardiac gap junction function and expression. Naunyn Schmiedebergs Arch Pharmacol, 2011; 383: 331-46. 
[72] Musil LS, Goodenough DA. Biochemical analysis of connexin43 intracellular transport, phosphorylation, and assembly into gap junctional plaques. J Cell Biol, 1991; 115: 1357-74.

[73] Duthe F, Plaisance I, Sarrouilhe D, Herve JC. Endogenous protein phosphatase 1 runs down gap junctional communication of rat ventricular myocytes. Am J Physiol Cell Physiol, 2001; 281: C1648-56.

[74] Herve JC, Dhein S. Pharmacology of cardiovascular gap junctions. Adv Cardiol, 2006; 42: 107-31.

[75] Beardslee MA, Lerner DL, Tadros PN, Laing JG, Beyer EC, Yamada KA, Kleber AG, Schuessler RB, Saffitz JE. Dephosphorylation and intracellular redistribution of ventricular connexin43 during electrical uncoupling induced by ischemia. Circ Res, 2000; 87: 656-62.

[76] Ai X, Pogwizd SM. Connexin 43 downregulation and dephosphorylation in nonischemic heart failure is associated with enhanced colocalized protein phosphatase type 2A. Circ Res, 2005; 96: 54-63.

[77] Solan JL, Marquez-Rosado L, Sorgen PL, Thornton PJ, Gafken PR, Lampe PD. Phosphorylation at $\mathrm{S} 365$ is a gatekeeper event that changes the structure of $\mathrm{Cx} 43$ and prevents down-regulation by PKC. J Cell Biol, 2007; 179: 1301-9.

[78] Solan JL, Lampe PD. Connexin43 phosphorylation: structural changes and biological effects. Biochem J, 2009; 419: 261-72.

[79] Green CR, Severs NJ. Robert Feulgen Prize Lecture. Distribution and role of gap junctions in normal myocardium and human ischaemic heart disease. Histochemistry, 1993; 99: 105-20.

[80] Peters AM, Bertram P, Gahr M, Speer CP. Reduced secretion of interleukin-1 and tumor necrosis factor-alpha by neonatal monocytes. Biol Neonate, 1993; 63: 157-62.

[81] Smith JH, Green CR, Peters NS, Rothery S, Severs NJ. Altered patterns of gap junction distribution in ischemic heart disease. An immunohistochemical study of human myocardium using laser scanning confocal microscopy. Am J Pathol, 1991; 139: 801-21.

[82] White RL, Doeller JE, Verselis VK, Wittenberg BA. Gap junctional conductance between pairs of ventricular myocytes is modulated synergistically by $\mathrm{H}+$ and $\mathrm{Ca}++. \mathrm{J}$ Gen Physiol, 1990; 95: 1061-75.

[83] Maurer P, Weingart R. Cell pairs isolated from adult guinea pig and rat hearts: effects of [Ca2+]i on nexal membrane resistance. Pflugers Arch, 1987; 409: 394-402.

[84] Lesh MD, Pring M, Spear JF. Cellular uncoupling can unmask dispersion of action potential duration in ventricular myocardium. A computer modeling study. Circ Res, 1989; 65: 1426-40.

[85] Shaw RM, Rudy Y. Ionic mechanisms of propagation in cardiac tissue. Roles of the sodium and L-type calcium currents during reduced excitability and decreased gap junction coupling. Circ Res, 1997; 81: 727-41.

[86] Wolk R, Cobbe SM, Hicks MN, Kane KA. Functional, structural, and dynamic basis of electrical heterogeneity in healthy and diseased cardiac muscle: implications for arrhythmogenesis and anti-arrhythmic drug therapy. Pharmacol Ther, 1999; 84: 20731.

[87] Coronel R, Fiolet JW, Wilms-Schopman FJ, Schaapherder AF, Johnson TA, Gettes LS, Janse MJ. Distribution of extracellular potassium and its relation to electrophysiologic changes during acute myocardial ischemia in the isolated perfused porcine heart. Circulation, 1988; 77: 1125-38.

[88] Carmeliet E. Cardiac ionic currents and acute ischemia: from channels to arrhythmias. Physiol Rev, 1999; 79: 917-1017. 
[89] Varro A, Baczko I. Cardiac ventricular repolarization reserve: a principle for understanding drug-related proarrhythmic risk. Br J Pharmacol, 2011; 164: 14-36.

[90] Cascio WE. Myocardial ischemia: what factors determine arrhythmogenesis? J Cardiovasc Electrophysiol, 2001; 12: 726-9.

[91] De Groot JR, Coronel R. Acute ischemia-induced gap junctional uncoupling and arrhythmogenesis. Cardiovasc Res, 2004; 62: 323-34.

[92] Kleber AG, Rudy Y. Basic mechanisms of cardiac impulse propagation and associated arrhythmias. Physiol Rev, 2004; 84: 431-88.

[93] Smith WTt, Fleet WF, Johnson TA, Engle CL, Cascio WE. The Ib phase of ventricular arrhythmias in ischemic in situ porcine heart is related to changes in cell-to-cell electrical coupling. Experimental Cardiology Group, University of North Carolina. Circulation, 1995; 92: 3051-60.

[94] Gonczi M, Papp R, Kovacs M, Seprenyi G, Vegh A. Modulation of gap junctions by nitric oxide contributes to the anti-arrhythmic effect of sodium nitroprusside? Br J Pharmacol, 2009; 156: 786-93.

[95] De Vuyst E, Boengler K, Antoons G, Sipido KR, Schulz R, Leybaert L. Pharmacological modulation of connexin-formed channels in cardiac pathophysiology. Br J Pharmacol, 2011; 163: 469-83.

[96] Gonczi M, Kovacs M, Seprenyi G, Vegh A. The involvement of gap junctions in the delayed phase of the protection induced by cardiac pacing in dogs. Clin Sci (Lond), 2012; 123: 39-51.

[97] Papp R, Gonczi M, Kovacs M, Seprenyi G, Vegh A. Gap junctional uncoupling plays a trigger role in the antiarrhythmic effect of ischaemic preconditioning. Cardiovasc Res, 2007; 74: 396-405.

[98] Dhein S, Hagen A, Jozwiak J, Dietze A, Garbade J, Barten M, Kostelka M, Mohr FW. Improving cardiac gap junction communication as a new antiarrhythmic mechanism: the action of antiarrhythmic peptides. Naunyn Schmiedebergs Arch Pharmacol, 2010; 381: 221-34.

[99] Weingart R, Maurer P. Action potential transfer in cell pairs isolated from adult rat and guinea pig ventricles. Circ Res, 1988; 63: 72-80.

[100] Aonuma S, Kohama Y, Akai K, Komiyama Y, Nakajima S, Wakabayashi M, Makino T. Studies on heart. XIX. Isolation of an atrial peptide that improves the rhythmicity of cultured myocardial cell clusters. Chem Pharm Bull (Tokyo), 1980; 28: 3332-9.

[101] Grover R, Dhein S. Structure-activity relationships of novel peptides related to the antiarrhythmic peptide AAP10 which reduce the dispersion of epicardial action potential duration. Peptides, 2001; 22: 1011-21.

[102] Weng S, Lauven M, Schaefer T, Polontchouk L, Grover R, Dhein S. Pharmacological modification of gap junction coupling by an antiarrhythmic peptide via protein kinase C activation. FASEB J, 2002; 16: 1114-6.

[103] Muller A, Gottwald M, Tudyka T, Linke W, Klaus W, Dhein S. Increase in gap junction conductance by an antiarrhythmic peptide. Eur J Pharmacol, 1997; 327: 6572.

[104] Kjolbye AL, Dikshteyn M, Eloff BC, Deschenes I, Rosenbaum DS. Maintenance of intercellular coupling by the antiarrhythmic peptide rotigaptide suppresses arrhythmogenic discordant alternans. Am J Physiol Heart Circ Physiol, 2008; 294 : H41-9.

[105] Jozwiak J, Dhein S. Local effects and mechanisms of antiarrhythmic peptide AAP10 in acute regional myocardial ischemia: electrophysiological and molecular findings. Naunyn Schmiedebergs Arch Pharmacol, 2008; 378: 459-70. 
[106] Kjolbye AL, Knudsen CB, Jepsen T, Larsen BD, Petersen JS. Pharmacological characterization of the new stable antiarrhythmic peptide analog Ac-D-Tyr-D-Pro-DHyp-Gly-D-Ala-Gly-NH2 (ZP123): in vivo and in vitro studies. J Pharmacol Exp Ther, 2003; 306: 1191-9.

[107] Dhein S, Larsen BD, Petersen JS, Mohr FW. Effects of the new antiarrhythmic peptide ZP123 on epicardial activation and repolarization pattern. Cell Commun Adhes, 2003; 10: 371-8.

[108] Rossman EI, Liu K, Morgan GA, Swillo RE, Krueger JA, Gardell SJ, Butera J, Gruver M, Kantrowitz J, Feldman HS, Petersen JS, Haugan K, Hennan JK. The gap junction modifier, GAP-134 [(2S,4R)-1-(2-aminoacetyl)-4-benzamido-pyrrolidine-2-carboxylic acid], improves conduction and reduces atrial fibrillation/flutter in the canine sterile pericarditis model. J Pharmacol Exp Ther, 2009; 329: 1127-33.

[109] Hennan JK, Swillo RE, Morgan GA, Rossman EI, Kantrowitz J, Butera J, Petersen JS, Gardell SJ, Vlasuk GP. GAP-134 ([2S,4R]-1-[2-aminoacetyl]4-benzamidopyrrolidine2-carboxylic acid) prevents spontaneous ventricular arrhythmias and reduces infarct size during myocardial ischemia/reperfusion injury in open-chest dogs. J Cardiovasc Pharmacol Ther, 2009; 14: 207-14.

[110] Butera JA, Larsen BD, Hennan JK, Kerns E, Di L, Alimardanov A, Swillo RE, Morgan GA, Liu K, Wang Q, Rossman EI, Unwalla R, McDonald L, Huselton C, Petersen JS. Discovery of (2S,4R)-1-(2-aminoacetyl)-4-benzamidopyrrolidine-2carboxylic acid hydrochloride (GAP-134)13, an orally active small molecule gapjunction modifier for the treatment of atrial fibrillation. J Med Chem, 2009; 52: 90811.

[111] Nattel S, Carlsson L. Innovative approaches to anti-arrhythmic drug therapy. Nat Rev Drug Discov, 2006; 5: 1034-49.

[112] Kjolbye AL, Holstein-Rathlou NH, Petersen JS. Anti-arrhythmic peptide N-3-(4hydroxyphenyl)propionyl Pro-Hyp-Gly-Ala-Gly-OH reduces dispersion of action potential duration during ischemia/reperfusion in rabbit hearts. J Cardiovasc Pharmacol, 2002; 40: 770-9.

[113] Laszczyk MN. Pentacyclic triterpenes of the lupane, oleanane and ursane group as tools in cancer therapy. Planta Med, 2009; 75: 1549-60.

[114] Davidson JS, Baumgarten IM. Glycyrrhetinic acid derivatives: a novel class of inhibitors of gap-junctional intercellular communication. Structure-activity relationships. J Pharmacol Exp Ther, 1988; 246: 1104-7.

[115] Chaytor AT, Martin PE, Evans WH, Randall MD, Griffith TM. The endothelial component of cannabinoid-induced relaxation in rabbit mesenteric artery depends on gap junctional communication. J Physiol, 1999; 520: 539-50.

[116] Allen T, Iftinca M, Cole WC, Plane F. Smooth muscle membrane potential modulates endothelium-dependent relaxation of rat basilar artery via myo-endothelial gap junctions. J Physiol, 2002; 545: 975-86.

[117] Shi Q, Hou Y, Hou J, Pan P, Liu Z, Jiang M, Gao J, Bai G. Glycyrrhetic acid synergistically enhances beta(2)-adrenergic receptor-Gs signaling by changing the location of Galphas in lipid rafts. PLoS One, 2012; 7: e44921.

[118] Du YM, Xia CK, Zhao N, Dong Q, Lei M, Xia JH. 18beta-Glycyrrhetinic acid preferentially blocks late Na current generated by DeltaKPQ Nav1.5 channels. Acta Pharmacol Sin, 2012; 33: 752-60.

[119] Connors BW. Tales of a dirty drug: carbenoxolone, gap junctions, and seizures. Epilepsy Curr, 2012; 12: 66-8. 
[120] Nuotio-Antar AM, Hachey DL, Hasty AH. Carbenoxolone treatment attenuates symptoms of metabolic syndrome and atherogenesis in obese, hyperlipidemic mice. Am J Physiol Endocrinol Metab, 2007; 293: E1517-28.

[121] Vessey JP, Lalonde MR, Mizan HA, Welch NC, Kelly ME, Barnes S. Carbenoxolone inhibition of voltage-gated $\mathrm{Ca}$ channels and synaptic transmission in the retina. $\mathrm{J}$ Neurophysiol, 2004; 92: 1252-6.

[122] Madry C, Haglerod C, Attwell D. The role of pannexin hemichannels in the anoxic depolarization of hippocampal pyramidal cells. Brain, 2010; 133: 3755-63.

[123] Rozental R, Srinivas M, Spray DC. How to close a gap junction channel. Efficacies and potencies of uncoupling agents. Methods Mol Biol, 2001; 154: 447-76.

[124] Salameh A, Dhein S. Pharmacology of gap junctions. New pharmacological targets for treatment of arrhythmia, seizure and cancer? Biochim Biophys Acta, 2005; 1719: 3658.

[125] Brokamp C, Todd J, Montemagno C, Wendell D. Electrophysiology of single and aggregate Cx43 hemichannels. PLoS One, 2012; 7: e47775.

[126] Song M, Yu X, Cui X, Zhu G, Zhao G, Chen J, Huang L. Blockade of connexin 43 hemichannels reduces neointima formation after vascular injury by inhibiting proliferation and phenotypic modulation of smooth muscle cells. Exp Biol Med (Maywood), 2009; 234: 1192-200.

[127] Goldberg GS, Moreno AP, Bechberger JF, Hearn SS, Shivers RR, MacPhee DJ, Zhang YC, Naus CC. Evidence that disruption of connexon particle arrangements in gap junction plaques is associated with inhibition of gap junctional communication by a glycyrrhetinic acid derivative. Exp Cell Res, 1996; 222: 48-53.

[128] Hecker E. Cocarcinogenic principles from the seed oil of Croton tiglium and from other Euphorbiaceae. Cancer Res, 1968; 28: 2338-49.

[129] Blumberg PM. Protein kinase $\mathrm{C}$ as the receptor for the phorbol ester tumor promoters: sixth Rhoads memorial award lecture. Cancer Res, 1988; 48: 1-8.

[130] Nishizuka Y. Studies and perspectives of protein kinase C. Science, 1986; 233: 30512.

[131] Banerjee D, Das S, Molina SA, Madgwick D, Katz MR, Jena S, Bossmann LK, Pal D, Takemoto DJ. Investigation of the reciprocal relationship between the expression of two gap junction connexin proteins, connexin46 and connexin43. J Biol Chem, 2011; 286: 24519-33.

[132] Lampe PD. Analyzing phorbol ester effects on gap junctional communication: a dramatic inhibition of assembly. J Cell Biol, 1994; 127: 1895-905.

[133] Warner A, Clements DK, Parikh S, Evans WH, DeHaan RL. Specific motifs in the external loops of connexin proteins can determine gap junction formation between chick heart myocytes. J Physiol, 1995; 488: 721-8.

[134] Evans WH, Bultynck G, Leybaert L. Manipulating connexin communication channels: use of peptidomimetics and the translational outputs. J Membr Biol, 2012; 245: 43749.

[135] Li H, Liu TF, Lazrak A, Peracchia C, Goldberg GS, Lampe PD, Johnson RG. Properties and regulation of gap junctional hemichannels in the plasma membranes of cultured cells. J Cell Biol, 1996; 134: 1019-30.

[136] Chaytor AT, Evans WH, Griffith TM. Peptides homologous to extracellular loop motifs of connexin 43 reversibly abolish rhythmic contractile activity in rabbit arteries. J Physiol, 1997; 503 99-110.

[137] Wright CS, van Steensel MA, Hodgins MB, Martin PE. Connexin mimetic peptides improve cell migration rates of human epidermal keratinocytes and dermal fibroblasts in vitro. Wound Repair Regen, 2009; 17: 240-9. 
[138] Pollok S, Pfeiffer AC, Lobmann R, Wright CS, Moll I, Martin PE, Brandner JM. Connexin 43 mimetic peptide Gap27 reveals potential differences in the role of Cx43 in wound repair between diabetic and non-diabetic cells. J Cell Mol Med, 2011; 15: 861-73.

[139] Ko K, Arora P, Lee W, McCulloch C. Biochemical and functional characterization of intercellular adhesion and gap junctions in fibroblasts. Am J Physiol Cell Physiol, 2000; 279: C147-57.

[140] Heiniger B, Gakhar G, Prasain K, Hua DH, Nguyen TA. Second-generation substituted quinolines as anticancer drugs for breast cancer. Anticancer Res, 2010; 30: 3927-32.

[141] Sepp R, Severs NJ, Gourdie RG. Altered patterns of cardiac intercellular junction distribution in hypertrophic cardiomyopathy. Heart, 1996; 76: 412-7.

[142] Yao JA, Hussain W, Patel P, Peters NS, Boyden PA, Wit AL. Remodeling of gap junctional channel function in epicardial border zone of healing canine infarcts. Circ Res, 2003; 92: 437-43.

[143] Kaplinsky E, Ogawa S, Balke CW, Dreifus LS. Two periods of early ventricular arrhythmia in the canine acute myocardial infarction model. Circulation, 1979; 60: 397-403.

[144] Menken U, Wiegand V, Bucher P, Meesmann W. Prophylaxis of ventricular fibrillation after acute experimental coronary occlusion by chronic beta-adrenoceptor blockade with atenolol. Cardiovasc Res, 1979; 13: 588-94.

[145] Wit Al Fau - Peters NS, Peters NS. The role of gap junctions in the arrhythmias of ischemia and infarction. Heart Rhythm, 2012; 9: 308-11.

[146] Tan RC, Joyner RW. Electrotonic influences on action potentials from isolated ventricular cells. Circ Res, 1990; 67: 1071-81.

[147] Pollard AE, Cascio WE, Fast VG, Knisley SB. Modulation of triggered activity by uncoupling in the ischemic border. A model study with phase 1b-like conditions. Cardiovasc Res, 2002; 56: 381-92.

[148] Eloff BC, Gilat E, Wan X, Rosenbaum DS. Pharmacological modulation of cardiac gap junctions to enhance cardiac conduction: evidence supporting a novel target for antiarrhythmic therapy. Circulation, 2003; 108: 3157-63.

[149] Dhein S, Weng S, Grover R, Tudyka T, Gottwald M, Schaefer T, Polontchouk L. Protein kinase Calpha mediates the effect of antiarrhythmic peptide on gap junction conductance. Cell Commun Adhes, 2001; 8: 257-64.

[150] Quan XQ, Bai R, Lu JG, Patel C, Liu N, Ruan Y, Chen BD, Ruan L, Zhang CT. Pharmacological enhancement of cardiac gap junction coupling prevents arrhythmias in canine LQT2 model. Cell Commun Adhes, 2009; 16: 29-38.

[151] Rohr S. Role of gap junctions in the propagation of the cardiac action potential. Cardiovasc Res, 2004; 62: 309-22.

[152] Wang Y, Rudy Y. Action potential propagation in inhomogeneous cardiac tissue: safety factor considerations and ionic mechanism. Am J Physiol Heart Circ Physiol, 2000; 278: H1019-29.

[153] Kanno S, Kovacs A, Yamada KA, Saffitz JE. Connexin43 as a determinant of myocardial infarct size following coronary occlusion in mice. J Am Coll Cardiol, 2003; 41: 681-6.

[154] Cinca J, Warren M, Carreno A, Tresanchez M, Armadans L, Gomez P, Soler-Soler J. Changes in myocardial electrical impedance induced by coronary artery occlusion in pigs with and without preconditioning: correlation with local ST-segment potential and ventricular arrhythmias. Circulation, 1997; 96: 3079-86. 
[155] Vegh A, Komori S, Szekeres L, Parratt JR. Antiarrhythmic effects of preconditioning in anaesthetised dogs and rats. Cardiovasc Res, 1992; 26: 487-95.

[156] Braet K, Aspeslagh S, Vandamme W, Willecke K, Martin PE, Evans WH, Leybaert L. Pharmacological sensitivity of ATP release triggered by photoliberation of inositol1,4,5-trisphosphate and zero extracellular calcium in brain endothelial cells. J Cell Physiol, 2003; 197: 205-13.

[157] Braet K, Vandamme W, Martin PE, Evans WH, Leybaert L. Photoliberating inositol1,4,5-trisphosphate triggers ATP release that is blocked by the connexin mimetic peptide gap 26. Cell Calcium, 2003; 33: 37-48.

[158] Leybaert L, Braet K, Vandamme W, Cabooter L, Martin PE, Evans WH. Connexin channels, connexin mimetic peptides and ATP release. Cell Commun Adhes, 2003; 10: 251-7.

[159] De Vuyst E, Wang N, Decrock E, De Bock M, Vinken M, Van Moorhem M, Lai C, Culot M, Rogiers V, Cecchelli R, Naus CC, Evans WH, Leybaert L. Ca(2+) regulation of connexin 43 hemichannels in C6 glioma and glial cells. Cell Calcium, 2009; 46: 176-87.

[160] John S, Cesario D, Weiss JN. Gap junctional hemichannels in the heart. Acta Physiol Scand, 2003; 179: 23-31.

[161] Hawat G, Benderdour M, Rousseau G, Baroudi G. Connexin 43 mimetic peptide Gap26 confers protection to intact heart against myocardial ischemia injury. Pflugers Arch, 2010; 460: 583-92.

[162] Kang J, Kang N, Lovatt D, Torres A, Zhao Z, Lin J, M N. Connexin 43 hemichannels are permeable to ATP. Journal of Neuroscience, 2008; 28: 4702-4711.

[163] Stahlhut M, Petersen JS, Hennan JK, Ramirez MT. The antiarrhythmic peptide rotigaptide (ZP123) increases connexin 43 protein expression in neonatal rat ventricular cardiomyocytes. Cell Commun Adhes, 2006; 13: 21-7.

[164] Clarke TC, Williams OJ, Martin PE, Evans WH. ATP release by cardiac myocytes in a simulated ischaemia model: inhibition by a connexin mimetic and enhancement by an antiarrhythmic peptide. Eur J Pharmacol, 2009; 605: 9-14.

[165] Tveito A, Lines GT, Maleckar MM. Note on a possible proarrhythmic property of antiarrhythmic drugs aimed at improving gap-junction coupling. Biophys J, 2012; 102: $231-7$. 


\section{Figures}

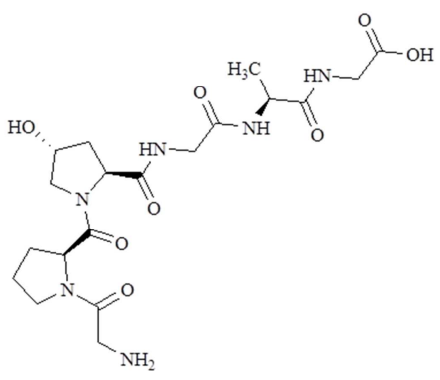

AAP

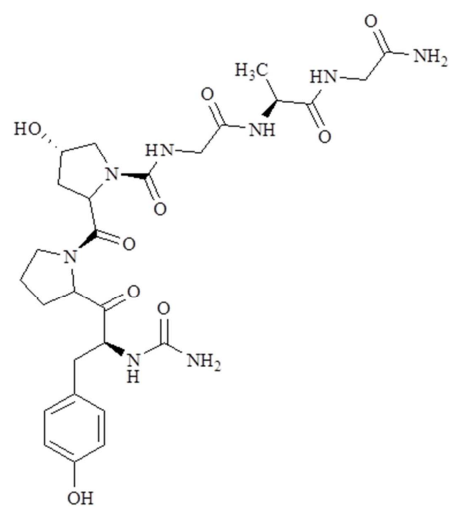

AAP10

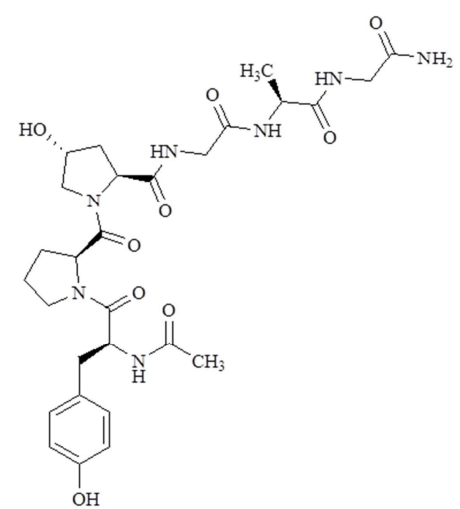

Rotigaptide

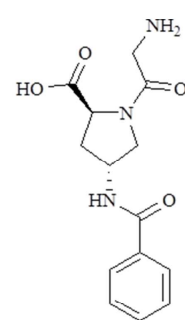

Danegaptide

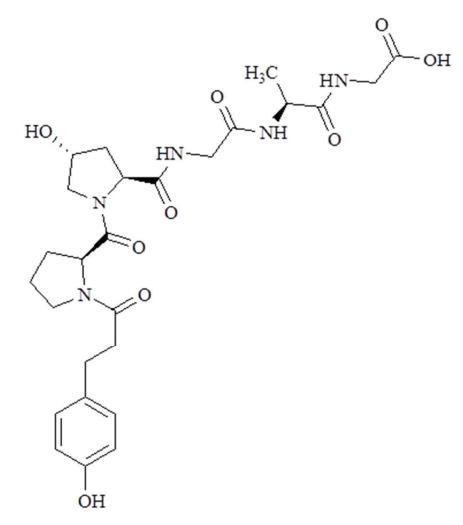

HP-5

Fig. (1). Gap junction enhancers

Chemical structure of AAP, AAP10, Rotigaptide (ZP123), Danegaptide (GAP134) and HP-5 (N-3-(4-hydroxyphenyl)propionyl) molecules. 


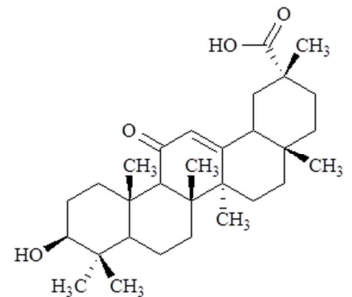

18-a-Glycyrrhetinic acid

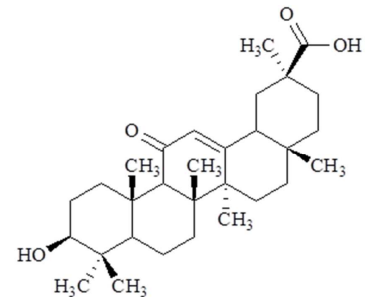

$18-\beta-G l y c y r r h e t i n i c ~ a c i d$

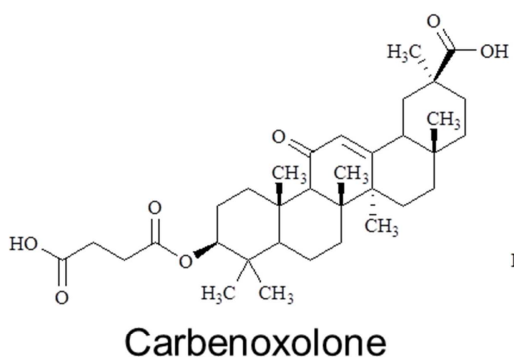

Carbenoxolone

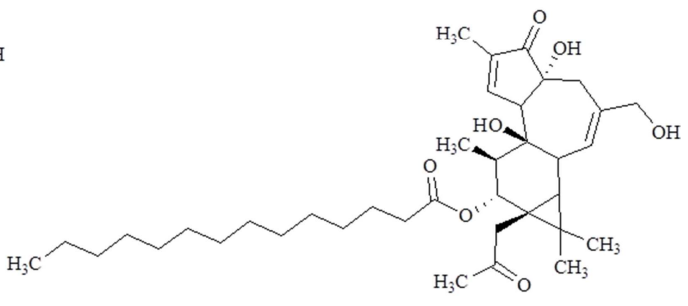

TPA

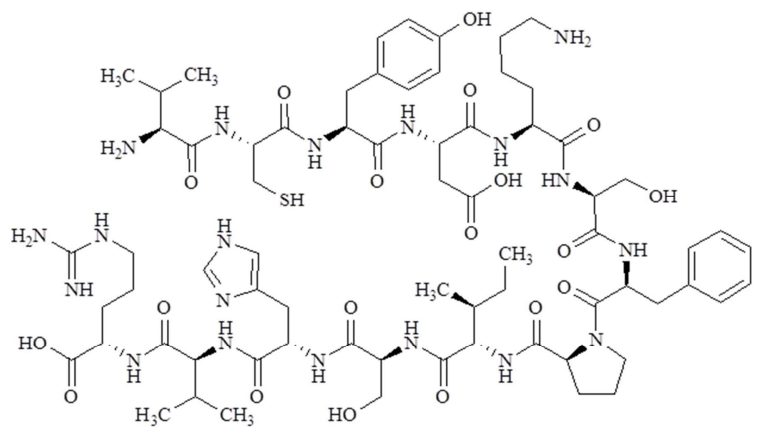

GAP 26

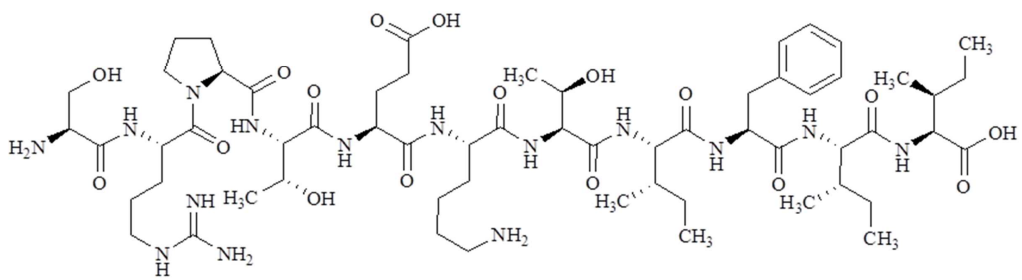

GAP 27

Fig. (2). Gap junction inhibitors

Chemical structure of 18- $\alpha$-Glycyrrhetinic acid and 18- $\beta$-Glycyrrhetinic acid, Carbenoxolone, Tetradecanoylphorbol acetate (TPA), GAP26 and GAP27 molecules. 